\title{
From Mediterranean to Scandinavia - timing and body mass condition in four long distance migrants
}

\author{
Från Medelhavet till Skandinavien - tidsmässigt uppträdande och energireserver \\ hos fyra långdistansflyttande tättingar
}

CHRISTOS BARBOUTIS, LEO LARSSON, ÅSA STEINHOLTZ \& THORD FRANSSON

\begin{abstract}
In spring, long-distance migrants are considered to adopt a time-minimizing strategy to promote early arrival at breeding sites. The phenology of spring migration was examined and compared between two insular stopover sites in Greece and Sweden for Icterine Warbler, Wood Warbler, Spotted Flycatcher and Collared Flycatcher. All of them migrate due north which means that some proportion of birds that pass through Greece are heading to Scandinavia. The Collared Flycatcher had the earliest and the Icterine Warbler the latest arrival time. The differences in median dates between Greece and Sweden were 3-4 weeks and the passages in Sweden were generally more condensed in time. The average overall speed estimates were very similar and varied between 129 and $137 \mathrm{~km} / \mathrm{d}$. In most of the species higher speed estimates were associated with years when birds arrived late in Greece. After crossing continental Europe birds

arrive at the Swedish study site with significantly higher body masses compared to when they arrive in Greece and this might indicate a preparation for arriving at breeding grounds with some overload.

Christos Barboutis, Antikythira Bird Observatory, Hellenic Ornithological Society, 80 Themistokleous str, GR-10681, Athens, Greece; Natural History Museum of Crete, University of Crete, PO Box 2208, 71409 Heraklion, Crete, Greece. Email: cbarboutis@ornithologiki.gr (corresponding author)

Leo Larsson \& Asa Steinholtz, Sundre Bird Observatory, Sundre, Skoge 518, SE-623 30 Burgsvik, Sweden

Thord Fransson, Department of Environmental Research and Monitoring, Swedish Museum of Natural History, Box 50 007, SE-104 05 Stockholm, Sweden
\end{abstract}

Received 8 January 2014, Accepted 23 March 2015, Editor: J. Waldenström

\section{Introduction}

According to optimal migration theory, a migratory bird might have to choose between minimizing the overall time on migration, energy expenditure or predation risk (Alerstam \& Lindström 1990). Recent data indicate that neither time minimization, nor minimization of total energy spent is the main single currency in bird migration (Schmaljohann \& Dierschke 2005, Hedenström 2008). In spring, the importance of reaching the breeding grounds early might give rise to a time-minimizing strategy rather than energy-minimization (Kokko 1999, Newton 2008). It has also been shown that the total duration of spring migration is shorter than autumn migration (Fransson 1995, Yohannes et al. 2009a, Nilsson et al. 2013).

Long distance migrating species that breed in Europe and winter in sub-Saharan Africa have to cross diverse ecological and geographical sectors during their migration towards their breeding grounds. As migrants need to optimally modulate their travel costs in relation to time, energy and safety while crossing those diverse sectors, migration speed and body mass might vary between different geographic sectors along the migration route (Bojarinova et al. 2008, Yohannes et al. 2009a, b). Furthermore, apart from the advantages of arriving early to the breeding grounds, the adaptive advantages of overloads at arrival have been discussed. It has been assumed that extra energy at arrival can affect breeding performance and act as an insurance against adverse weather and reduced food resources during the days following arrival (Sandberg 1996, Sandberg \& Moore 1996). It is well established that several bird species have advanced their spring migration with the current climate changes (e.g. Hüppop \& Hüppop 2003, Stervander et al. 2005, Thorup et al. 2007, Hedlund et al. 2014), which makes it important to follow and analyse the phenology of migratory birds.

In this study, the timing and phenology of spring migration and arrival body mass of Icterine Warbler 
Hippolais icterina, Wood Warbler Phylloscopus sibilatrix, Spotted Flycatcher Muscicapa striata and Collared Flycatcher Ficedula albicollis were examined in two sites. Comparisons were made between the two stopover sites, one in southern and one in northern Europe and the migration speed of the four species between the two study sites was estimated. The included species, with exception of the Collared Flycatcher, breed in large areas of Scandinavia. The Collared Flycatcher breeds mainly on the islands Gotland and Öland in the Baltic. All of them have in common that they migrate more or less straight north during spring migration from wintering areas in Africa to breeding areas in Europe (Bakken et al. 2006, Bønløkke et al. 2006, Fransson \& Hall-Karlsson 2008, Valkama et al. 2014).

\section{Materials and methods}

Data used in this study were collected at Antikythira Bird Observatory $\left(35^{\circ} 51^{\prime} \mathrm{N}, 23^{\circ} 18^{\prime} \mathrm{E}\right)$, Greece and at Hoburgen, $\left(56^{\circ} 33^{\prime} \mathrm{N}, 18^{\circ} 05^{\prime} \mathrm{E}\right)$, Gotland, Sweden (Figure 1a) during eight consecutive spring migration periods (2007 through 2014). Hoburgen is situated approximately $2370 \mathrm{~km}$ north of Antikythira in a $352^{\circ}$ direction. The ringing of migrants at Antikythira is run by the Hellenic Ornithological Society and the Hellenic Bird Ringing Centre and takes place between the end of March and the end of May. The ringing at Hoburgen is run by Sundre Bird Observatory and takes place between 25 April and 8 June. Mist netting at Antikythira took place every day from dawn and thereafter for eight hours and at Hoburgen from dawn and at least until 10.00 a.m., except for days with adverse weather conditions. Trapped birds were identified according to Svensson (1992) and weighed to the nearest $0.1 \mathrm{~g}$. Maximum wing length (Svensson 1992) was recorded as a measurement of size. Visible subcutaneous fat stores were estimated according to Kaiser (1993) for birds trapped at Antikythira and according to a scale based on Pettersson \& Hasselquist (1985) for birds trapped at Hoburgen. The trapping effort barely differed between years for both sites, regarding both total length of nets and the positions of mist nets used.

Migration speed estimates, for each of the four species studied, were calculated on population level and based on differences in median passage of a species at the two locations along the migration route. Median dates were measured as dates when the cumulative number of ringed birds passed $50 \%$ of the total capture in a given location.

A size sensitive body mass index (body mass/ wing length ${ }^{3}$ cf. Ekman \& Hake 1990) was used, when comparing body masses of the study species
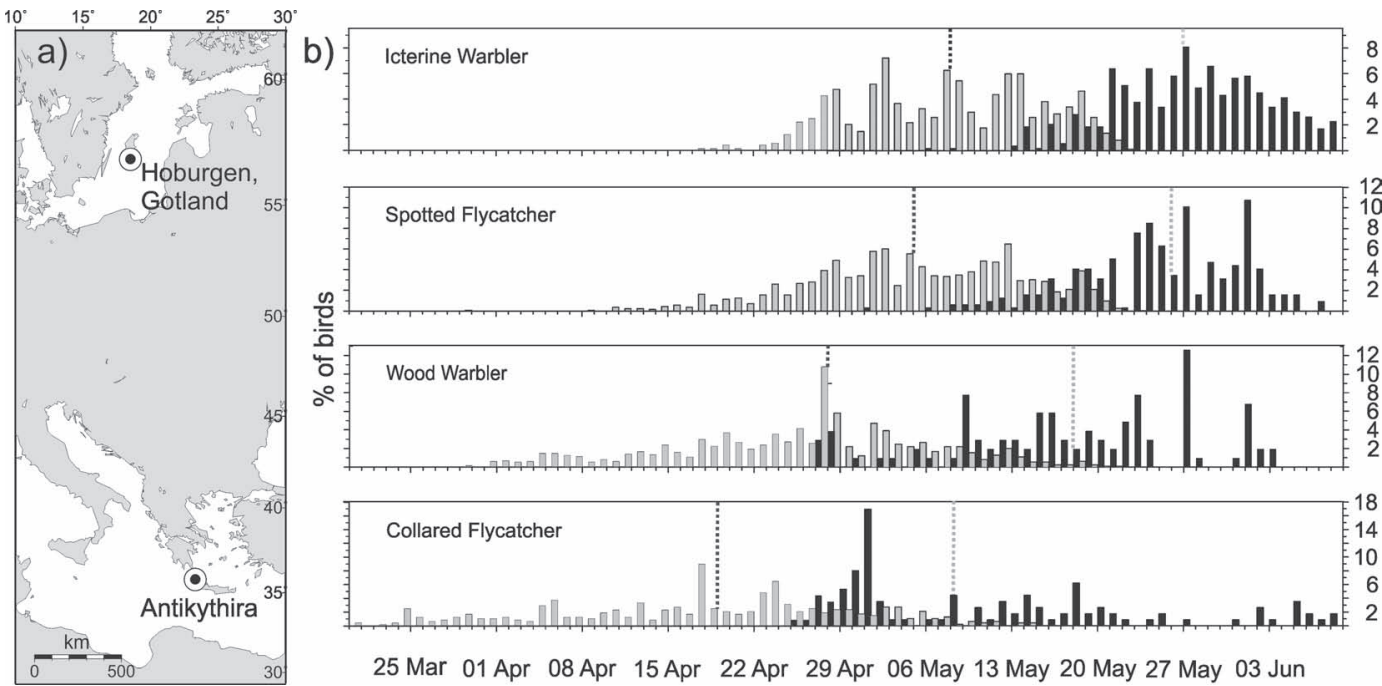

Figure 1. a) Location of the study sites. b) Spring migration phenology of the studied species at Antikythira (grey bars) and Hoburgen (black bars) during 2007-2014. Median passage dates are shown by dotted lines (black for Antikythira and grey for Hoburgen).

a) Geografiskt läge för de två lokalerna. b) De studerade arternas tidsmässiga uppträdande under flyttningen vid Antikythira (gråa staplar) och vid Hoburgen (svarta staplar) vårarna 2007-2014. Mediandatum visas med prickig linje (svart för Antikythira och grå för Hoburgen). 
between the two sites. When the criteria for parametric tests were met they were chosen to compare body mass indexes of species between sites and when this was not met, the equivalent non-parametric tests were performed.

\section{Results}

In total 4157 and 1062 birds belonging to the four study species were trapped at Antikythira and Hoburgen, respectively (Table 1).

The median arrival dates of Icterine Warbler, Wood Warbler, Spotted Flycatcher and Collared Flycatcher varied between 19 April and 8 May at Antikythira and between 8 and 27 May at Gotland. The median arrival dates differed significantly between the species at Antikythira (Kruskal-Wallis, $\mathrm{H}=25.35 \mathrm{df}=3, \mathrm{p}=0.0001)$ with the median arrival dates of the Icterine Warbler and the Spotted Flycatcher being different from the median arrival date of the Wood Warbler and the Collared Flycatcher (Mann-Whitney pairwise, Bonferonni corrected; Icterine Warbler vs. Wood Warbler: $\mathrm{p}=0.005$, Icterine Warbler vs. Collared Flycatcher: $\mathrm{p}=0.05$, Spotted Flycatcher vs. Wood Warbler : $\mathrm{p}=0.007$, Spotted Flycatcher vs. Collared Flycatcher: $\mathrm{p}=0.005$ ). Likewise the median arrival dates differed between the study species at Hoburgen (Kruskal-Wallis, $\mathrm{H}=23.0 \mathrm{df}=3, \mathrm{p}<0.001$ ), with significant differences recorded between the Icterine Warbler and both the Wood Warbler and Collared Flycatcher
(Mann-Whitney pairwise, Bonferonni corrected; Icterine Warbler vs. Wood Warbler: $p=0.009$, Icterine Warbler vs. Collared Flycatcher: $\mathrm{p}=0.005$ ) and the Spotted Flycatcher and the Collared Flycatcher $(p=0.006)$. The differences between the first birds to be trapped and the median passages (Figure 1b) are larger at Antikythira, which shows that the passages are more condensed at Hoburgen.

The migration speed based on the median passages of the populations at our two study sites varied very little (Table 2 ) and did not differ significantly between species (Kruskal-Wallis, $\mathrm{H}=1.89$ $\mathrm{df}=3, \mathrm{P}=0.593$ ). The calculated migration speed was significantly correlated with the median date of arrival at Antikythira in the Icterine Warbler (Spearman rank correlation, $r_{s}=0.85, p=0.001$ ) the Spotted Flycatcher $\left(r_{s}=0.68, p=0.047\right)$ and the Collared Flycatcher $(\mathrm{r}=0.58, \mathrm{p}=0.001)$ but not for the Wood Warbler $\left(r_{\mathrm{s}}=0.65, \mathrm{p}=0.071\right)$.

Concerning the wing length, the Icterine Warblers $(U=86602, Z=-16.51, p<0.001)$ and the Spotted Flycatchers $(U=180550, Z=-5.51, p<0.001)$ had on average slightly longer wings at Antikythira than at Hoburgen (Table 3) while no differences were detected for the Wood Warbler ( $U=71705$, $\mathrm{Z}=-0.91, \mathrm{p}=0.362$ ) and the Collared Flycatchers $(\mathrm{U}=18577, \mathrm{Z}=-1.33, \mathrm{p}=0.185)$.

The average arrival body mass for all species was significantly lower for birds at Antikythira compared with Hoburgen (Table 3; Icterine Warbler: $\mathrm{U}=84724, \mathrm{Z}=-16.6, \mathrm{p}<0.001$; Spotted Flycatch-

Table 1. Annual numbers trapped of the studied species at Antikythira and Hoburgen in spring during 2007-2014. Antalet årligen ringmärkta fäglar av de studerade arterna vid Antikythira och Hoburgen under vårarna $2007-2014$.

\begin{tabular}{|c|c|c|c|c|c|c|c|c|c|}
\hline Year $A r$ & 2007 & 2008 & 2009 & 2010 & 2011 & 2012 & 2013 & 2014 & Total \\
\hline \multicolumn{10}{|l|}{ Antikythira } \\
\hline $\begin{array}{l}\text { Icterine Warbler } \\
\text { Härmsångare }\end{array}$ & 125 & 84 & 92 & 68 & 78 & 162 & 66 & 54 & 729 \\
\hline $\begin{array}{l}\text { Spotted Flycatcher } \\
\text { Grå flugsnappare }\end{array}$ & 208 & 198 & 141 & 171 & 160 & 275 & 176 & 100 & 1429 \\
\hline $\begin{array}{l}\text { Wood Warbler } \\
\text { Grönsångare }\end{array}$ & 422 & 122 & 170 & 188 & 83 & 327 & 102 & 106 & 1520 \\
\hline $\begin{array}{l}\text { Collared Flycatcher } \\
\text { Halsbandsflugsnappare }\end{array}$ & 71 & 57 & 28 & 79 & 50 & 67 & 98 & 29 & 479 \\
\hline \multicolumn{10}{|l|}{ Hoburgen } \\
\hline $\begin{array}{l}\text { Icterine Warbler } \\
\text { Härmsångare }\end{array}$ & 55 & 97 & 53 & 59 & 40 & 59 & 67 & 101 & 531 \\
\hline $\begin{array}{l}\text { Spotted Flycatcher } \\
\text { Grå flugsnappare }\end{array}$ & 9 & 57 & 14 & 42 & 12 & 53 & 84 & 45 & 316 \\
\hline $\begin{array}{l}\text { Wood Warbler } \\
\text { Grönsångare }\end{array}$ & 5 & 9 & 5 & 16 & 3 & 15 & 29 & 21 & 103 \\
\hline $\begin{array}{l}\text { Collared Flycatcher } \\
\text { Halsbandsflugsnappare }\end{array}$ & 3 & 9 & 1 & 18 & 8 & 34 & 6 & 33 & 112 \\
\hline
\end{tabular}


Table 2. Median date of spring passage of the studied species at Antikythira and Hoburgen and estimated migration speed between the two sites.

Mediandatum för de olika arternas vårpassage av Antikythira och Hoburgen samt beräknad flyttningshastighet.

\begin{tabular}{|c|c|c|c|}
\hline \multirow[b]{2}{*}{ Species Art } & \multicolumn{2}{|c|}{$\begin{array}{l}\text { Median date (1st, 3rd quartiles) } \\
\text { Mediandatum (1:a, 3:e kvartilen) }\end{array}$} & \multirow{2}{*}{$\begin{array}{l}\text { Migration speed } \\
(\mathrm{km} / \mathrm{d} \pm \mathrm{SD}) \\
\text { Flyttningshastighet } \\
(\mathrm{km} / \mathrm{d} \pm \mathrm{SD})\end{array}$} \\
\hline & Antikythira & Hoburgen & \\
\hline $\begin{array}{l}\text { Icterine Warbler } \\
\text { Härmsångare }\end{array}$ & 8 May (2 May, 14 May) & 27 May (23 May, 1 Jun) & $137 \pm 39$ \\
\hline $\begin{array}{l}\text { Spotted Flycatcher } \\
\text { Grå flugsnappare }\end{array}$ & 5 May (29 April, 12 May) & 25 May (21 May, 30 May) & $135 \pm 24$ \\
\hline $\begin{array}{l}\text { Wood Warbler } \\
\text { Grönsångare }\end{array}$ & 28 April (20 April, 3 May) & 18 May (11 May, 27 May) & $129 \pm 45$ \\
\hline $\begin{array}{l}\text { Collared Flycatcher } \\
\text { Halsbandsflugsnappare }\end{array}$ & 19 April (10 April, 27 April) & 08 May (1 May, 18 May) & $134 \pm 90$ \\
\hline
\end{tabular}

er: $U=53746, Z=-20.9, p<0.001$; Wood Warbler: $\mathrm{U}=22291, \mathrm{Z}=-12.0, \mathrm{p}>0.001$; Collared Flycatcher: $\mathrm{U}=6184.0, \mathrm{Z}=-10.4, \mathrm{p}>0.001)$. Likewise the arrival body mass index was significantly different between Antikythira compared with Hoburgen (Icterine Warbler: $U=53398 \mathrm{Z}=-21.4, \mathrm{p}<0.001$; Wood Warbler: $U=28515, Z=-10.5, p>0.001$; Spotted Flycatcher: $U=57614, Z=-20.3, p<0.001$; Collared Flycatcher: $U=6161, Z=-10.2, p>0.001)$.

The average fat score varied from $1.3 \pm 1.2$ to 2.3 \pm 1.3 for birds arriving at Antikythira and from 2.6 \pm 1.4 to $3.0 \pm 1.5$ for birds arriving to Hoburgen (Table 4).

\section{Discussion}

Capture data from Antikythira indicate that the earliest among our study species to arrive in Europe is the Collared Flycatcher with the median passage of the species being similar to those that have been reported for Italy (Spina et al. 1993, Rubolini et al. 2005). The next species to arrive, with a median passage ten days later, is the Wood Warbler. Similar overall phenology pattern and date of median passages are described for Italy (Pettersson et al. 1990, Spina et al. 1993, Rubolini et al. 2005), France (Blondel \& Isenmann 1981) and Western Mediterranean and NW Africa (Gargallo et al. 2011). The Spotted Flycatcher and the Icterine Warbler are arriving within the first days of May. For the Spotted Flycatcher similar values of median passage have been reported throughout the whole Mediterranean (Spina et al. 1993, Rubolini et al. 2005, Gargallo et al. 2011). The pattern observed on Antikythira for the Icterine Warbler is similar to the one at a central Mediterranean island (Rubolini et al. 2005), while

Table 3. Average $( \pm \mathrm{SD})$ body mass, wing length and fat score of the studied species at Antikythira and Hoburgen (sample size in brackets).

Genomsnittlig ( $\pm S D)$ vikt, vinglängd och fettklass hos de studerade arterna vid Antikythira och Hoburgen (antal anges inom parentes).

\begin{tabular}{lllllll} 
& \multicolumn{2}{c}{ Body mass } & Vikt $(g)$ & \multicolumn{2}{c}{ Wing length Vinglängd (mm) } & \multicolumn{2}{c}{ Fat Score } & Fettklass \\
Species Art & Antikythira & Hoburgen & Antikythira & Hoburgen & Antikythira $^{1}$ & Hoburgen $^{2}$ \\
\hline Icterine Warbler & $12.2 \pm 1.42$ & $13.4 \pm 0.9$ & $80.7 \pm 2.01$ & $78.7 \pm 1.88$ & $2.3 \pm 1.3$ & $2.9 \pm 1.3$ \\
Härmsångare & $(715)$ & $(526)$ & $(719)$ & $(528)$ & $(717)$ & $(525)$ \\
Spotted Flycatcher & $13.3 \pm 1.47$ & $15.5 \pm 1.44$ & $89.2 \pm 2.32$ & $88.7 \pm 2.09$ & $1.4 \pm 1.2$ & $2.9 \pm 1.5$ \\
Grå flugsnappare & $(1398)$ & $(314)$ & $(1402)$ & $(314)$ & $(1385)$ & $(313)$ \\
Wood Warbler & $8.3 \pm 0.94$ & $9.6 \pm 0.91$ & $75.7 \pm 2.80$ & $75.5+2.54$ & $1.6 \pm 1.1$ & $2.8 \pm 1.6$ \\
Grönsångare & $(1471)$ & $(103)$ & $(1471)$ & $(103)$ & $(1445)$ & $(97)$ \\
Collared Flycatcher & $11.6 \pm 1.27$ & $13.2 \pm 0.97$ & $83.0 \pm 2.31$ & $82.7 \pm 1.90$ & $1.8 \pm 1.3$ & $3.0 \pm 1.5$ \\
Halsbandsflugsnappare & $(455)$ & $(89)$ & $(458)$ & $(89)$ & $(448)$ & $(86)$ \\
\hline
\end{tabular}

1: fat scores according to Kaiser (1993); 2: fat scores according to Pettersson \& Hasselquist (1985) 
the peak of the passage appears to be a little bit later in the Western Mediterranean and NW Africa (Gargallo et al. 2011).

The first birds of all the four species arrive to Gotland before the end of the passages at Antikythira and in the extreme cases (Wood Warbler and Icterine Warbler) just some days after the median passage at Antikythira (Figure 1). The median passage of all the study species on Gotland were within the range of previously reported median passage dates for Ottenby (Enquist \& Pettersson 1986, Stervander et al. 2005, Jonzén et al. 2006).

Birds arriving at Antikythira have just passed the Sahara desert and the Mediterranean Sea. There is recent evidence that species adapted to mesophilic and moist woodland have problems to refuel during migration in dry regions (Jenni-Eiermann et al. 2011), like those of North Africa. Depleted fuel reserves after the crossing have been reported several times in areas of central and eastern Mediterranean (e.g. Barboutis et al. 2011, Barboutis et al. 2013). The average arrival body mass and fat score of the Spotted Flycatcher was in the low range of values described in other Mediterranean sites (Spina et al. 1993, Waldenström et al. 2004, Gargallo et al. 2011) and indicates no major refueling events before the sea crossing. As the Spotted Flycatcher is thought to able stop and refuel during the crossing of the Sahara (Biebach 1985), the small variation in arrival body mass that exists throughout the Mediterranean islands could depend on the take-off point in North Africa and the length of the sea stretches birds have to cross. The fat scores and body masses of the Wood Warbler and the Collared Flycatcher were within the range of previously described values for the Mediterranean (Pettersson et al. 1990, Spina et al. 1993, Waldenström et al. 2004, Gargallo et al. 2011, Flint \& Stewart 1983).

The Icterine Warbler reached Antikythira with considerable fat stores and body mass, taking into consideration the season and geographical position. The arrival body mass at Antikythira was higher compared to birds of the same species at islands of central Mediterranean (Spina et al. 1993). This indicates that Icterine Warbler might have refueled in North Africa before reaching our study site. The higher arrival body masses at coastal and insular localities in Spain compared to North Morocco indicates the same pattern in the western Mediterranean (Gargallo et al. 2011).

After crossing more than $2000 \mathrm{~km}$ over continental Europe and about $250 \mathrm{~km}$ over the Baltic Sea our study species arrived at Gotland with significantly higher body masses compared with the ones they have when they arrive to Antikythira. As some of our study species were larger in size at Antikythira in comparison to with Gotland, the arrival body mass between the two stopover sites has been compared after correcting for size. It is well documented that passerines regularly reach their northern breeding grounds with an overload of fuel stores (Ojanen 1984, Sandberg 1996, Fransson \& Jakobsson 1998, Widmer \& Biebach 2001, Smith \& Moore 2005), the advantages of that have been discussed by Sandberg \& Moore (1996). The birds trapped at Hoburgen have overcome the majority of their migration journey and are close to their destinations and thus are expected to have started to carry this overload in preparation for the arrival at breeding grounds. The strategy adopted to obtain this overload is not clear. Birds might progressively accumulate fuel load throughout their migration in Europe, or at few, very specific locations, but this cannot be shown with the data obtained in this study.

Migration speed is commonly estimated from bird ringing recoveries (Hyytiä \& Vikberg 1973, Hildén \& Saurola 1982, Ellegren 1990, 1993, Bojarinova et al. 2008, Bensch \& Nielsen 1999, Payevsky 2010) or from median passage dates along the migratory route (Raess 2008, Yohannes et al. 2009a) or a combination of both (Fransson 1995). Estimating migration speed from arrival dates or median passage dates along a migratory route has been accused for not giving reliable values (Hildén \& Saurola 1982, Payevsky 2010). Ellegren (1990) however, concluded that estimating migration speed from ringing recoveries and from phenology data leads to similar results, and the method of using phenology data has been adopted in several more recent studies (e.g. Raess 2008, Yohannes et al. 2009a).

One could expect that species that initiate their migration early from their wintering grounds would have a slower migration speed compared to species departing late (Yohannes et al. 2009a). Our data does not support this within Europe as no significant difference was detected between species studied. The fact that higher speed estimates were associated with years when birds arrive late to Greece indicates that such a pattern is found within species. This might be driven by the importance of reaching the breeding grounds early (Kokko 1999, Newton 2008). It has been shown that migrants can adjust their migration speed to actual conditions en route (Tøttrup et al. 2008) and there might be environmental restrictions that reduce the migration speed from the Mediterranean to Scandinavia during years when birds arrive early to Europe (Both 2010). 
Most of the European populations of Wood Warbler and Collared Flycatcher breed south of our study site on Gotland, the majority of the populations of Icterine Warbler and Spotted Flycatcher breed either north or significantly east of Gotland (BirdLife International 2004). The difference in wing length between the two sites for some of the species might indicate that at least a portion of birds passing Antikythira move towards different areas than birds passing Gotland. Furthermore, the more condensed passage observed on Gotland might be a result of the fact that birds passing this site are heading for more restricted breeding areas compared with birds passing Antikythira.

In conclusion, the results show that it takes about three weeks for the studied species to migrate from Greece to Scandinavia and that they are much lighter when arriving to Europe compared with when they approach breeding areas further north. The migration speed performed by the study species is equivalent to values previously reported (Fransson 1986, Jonzén et al. 2006, Yohannes et al. 2009a) and faster than estimated during autumn migration (Hildén \& Saurola 1982, Fransson 1986).

\section{Acknowledgments}

This is contribution No. 17 from Antikythira Bird Observatory, a project run by the Hellenic Ornithological Society and No. 78 from Sundre Bird Observatory. Thanks two anonymous referees for valuable comments on the manuscript. Thanks also to all ringers and helpers that participated in the data collection. Rings were supplied free of charge by the Hellenic Bird Ringing Centre. Antikythira Bird Observatory is funded from A.G. and A.P Leventis Foundation.

\section{References}

Alerstam, T. \& Lindström, Å. 1990. Optimal bird migration: the relative importance of time, energy, and safety. Pp. 331-351 in Bird migration: physiology and ecophysiology (ed. Gwinner, E.). Springer-Verlag, Berlin.

BirdLife International. 2004. Birds in Europe: population estimates, trends and conservation status. (BirdLife Conservation Series No. 12). BirdLife nternational, Cambridge, U.K.

Bakken, V., Runde, O. \& Tjørve, E. 2006. Norsk ringmerkingsatlas. Vol 2. Stavanger Museum, Stavanger.

Barboutis, C., Evangelidis, A., Akriotis, T. \& Fransson, T. 2013. Spring migration phenology and arrival conditions of the Eastern Bonelli's Warbler and the Semi-collared Flycatcher at a small Greek island. Ringing \& Migration 28: 39-42.

Barboutis, C., Mylonas, M. \& Fransson, T. 2011. Breast muscle variation before and after crossing large ecological barriers in a small migratory passerine (Sylvia borin, Boddaert 1783). Journal of Biological Research-Thessaloniki 16: 159-165.

Bensch, S. \& Nielsen, B. 1999. Autumn migration speed of juvenile Reed and Sedge Warblers in relation to date and fat loads. Auk 101: 153-156.

Biebach, H. 1985. Sahara stopover in migratory flycatchers: fat and food affect the time program. Experiencia 41: 695-697.

Blondel, J. \& Isenmann, P., 1981. Guide des Oiseaux de Camargue. Delachaux et Niestlé, Neuchatel.

Bojarinova, J., Ilves A., Chernetsov, N. \& Leivits, A. 2008. Body mass, moult and migration speed of the Goldcrest Regulus regulus in relation to the timing of migration at different sites of the migration route. Ornis Fennica 85: 55-65.

Both, C. 2010. Flexibility of timing of avian migration to climate change masked by environmental constraints en route. Current Biology 20: 243-248.

Bønløkke, J., Madsen, J. J., Thorup, K., Pedersen, K. T. Bjerrum, M. \& Rahbek, C. 2006. Dansk Traekfugleatlas. Rhodos, Humlebæk.

Ekman J. B. \& Hake, M. K. 1990: Monitoring starvation risk: adjustments of body reserves in greenfinches ( $\mathrm{Car}$ duelis chloris L.) during periods of unpredictable foraging success. Behavioral Ecology 1: 62-67.

Ellegren, H. 1990. Autumn migration speed in Scandinavian Bluethroats Luscinia s. svecica. Ringing \& Migration 11: 121-131.

Ellegren, H. 1993. Speed of migration and migratory flight lengths of passerine birds ringed during autumn migration in Sweden. Ornis Scandinavica 24: 220-228.

Enquist, M. \& Pettersson, J. 1986. Flyttningens tidsmässiga förlopp hos 104 fägelarter vid Ottenby - en analys baserad på 39 års fängstdata. Degerhamn, Ottenby Bird Observatory.

Flint, P. R. \& Stewart, P.F. 1983. The Birds of Cyprus. B.O.U. Check list No. 6. British Ornithologists Union.

Fransson, T. \& Hall-Karlsson, S. 2008. Svensk ringmärkningsatlas. Vol. 3. Stockholm.

Fransson, T. \& Jakobsson, S. 1998. Fat storage in male willow warblers in spring: do residents arrive lean or fat? Auk 115: 759-763.

Fransson, T. 1986. Flyttning och övervintring hos nordiska grå flugsnappare Muscicapa striata. Vår Fågelvärld 45: 5-18. (in Swedish with an English summary)

Fransson, T. 1995. Timing and speed of migration in North and West European populations of Sylvia warblers. Journal of Avian Biology 26: 39-48.

Gargallo, G., Barriocanal, C., Castany J., Clarabuch, O., Escandell, R., López-Iborra, G,. Rguibi-Idrissi, H., Robson D. \& Suárez M. 2011. Spring migration in the western Mediterranean and NW Africa: the results of 16 years of the Piccole Isole project. Monografies del Museu de Ciències Naturals 6. Barcelona, Spain

Hedenström. A, 2008. Adaptations to migration in birds: behavioural strategies, morphology and scaling effects. Philosophical Transactions of the Royal Society of London B Biological Sciences 363: 287-299.

Hildén, O. \& Saurola, P. 1982. Speed of autumn migration of birds ringed in Finland. Ornis Fennica 59: 140-143.

Högstedt, G. \& Persson, C. 1971. Phänologie und Überwin- 
terung der über Falsterbo ziehenden Rotkelchen (Erithacus rubecula). Vogelwarte 26: 86-98. (In German).

Högstedt, G. \& Persson, C. 1982. Do willow warblers Phylloscopus trochilus of northern origin start their autumn migration at an earlier age than their southern conspecifics? Holarctic Ecology 5: 76-80.

Hüppop, O. \& Hüppop, K. 2003. North Atlantic oscillation and timing of spring migration in birds. Proceedings of the Royal Society of London B Biological Sciences 270: 233-240.

Hyytiä, K. \& Vikberg, P. 1973. Autumn migration and moult of the Spotted Flycatcher Muscicapa striata and the Pied Flycatcher Ficedula hypoleuca at the Signilskär bird station. Ornis Fennica 50: 134-143.

Jenni-Eiermann, S., Almasi, B., Maggini, I., Salewski, V., Bruderer, B., Liechti, F. \& Jenni, L. 2011. Numbers, foraging and refuelling of passerine migrants at a stopover site in the western Sahara: diverse strategies to cross a desert. Journal of Ornithology 152 (suppl. 1): 113-128.

Jonzén, N., Piacentini, D., Andersson, A., Montemaggiori, A., Stervander, M., Rubolini, D., Waldenström, J. \& Spina, F. 2006. The timing of spring migration in trans-Sharan migrants: a comparison between Ottenby, Sweden and Capri, Italy. Ornis Svecica 16: 27-33.

Kaiser, A. 1993. A new multi-category classification of subcutaneous fat deposits of songbirds. Journal of Field Ornithology 64: 246-255.

Kokko, H. 1999. Competition for early arrival in migratory birds. Journal of Animal Ecology 68: 940-950.

Newton, I. 2008. The Migration Ecology of Birds. Oxford, Academic Press.

Nilsson, C., Klaassen, R.H.G. \& Alerstam, T. 2013. Differences in Speed and Duration of Bird Migration between Spring and Autumn. The American Naturalist 181: 837845

Ojanen, M. 1984. The relation between spring migration and the onset of breeding in the pied flycatcher Ficedula hypoleuca in northern Finland. Annales Zoologici Fennici 21: 205-208.

Payevsky, V.A. 2010. Autumn migration speed of the Chaffinch (Fringilla coelebs L.) migrating across Europe as shown by ringing results in Eastern Baltic. Proceedings of the Zoological Institute RAS 314: 58-66.

Pettersson, J. \& Hasselquist, D. 1985. Fat deposition and migration capacity of robins Erithacus rubecula and goldcrests Regulus regulus at Ottenby, Sweden. Ringing \& Migration 6: 66-76.

Pettersson, J., Hjort, C., Gezelius, L. \& Johansson, J. 1990. Spring Migration of Birds on Capri. Degerhamn, Ottenby Bird Observatory.

Raes, M. 2008: Continental efforts: migration speed in spring and autumn in an inner-Asian migrant. Journal of Avian Biology 39: 13-18.

Rubolini, D., Spina, F. \& Saino, N., 2005. Correlates of timing of spring migration in birds: a comparative study of trans-Saharan migrants. Biological Journal of the Linnean Society 85: 199-210.

Sandberg, R. \& Moore, F. R. 1996. Fat stores and arrival on the breeding grounds: reproductive consequences for passerine migrants. Oikos 77: 577-581.

Sandberg, R. 1996. Fat reserves of migrating passerines at arrival on the breeding grounds in Swedish Lapland. Ibis 138: 514-524.
Schmaljohann, H. \& Dierschke, V. 2005. Optimal bird migration and predation risk: a field experiment with northern wheatears Oenanthe oenanthe. Journal of Animal Ecology 74: 131-138.

Smith, R. J. \&. Moore, F. R. 2005. Fat stores of American redstarts Setophaga ruticilla arriving at northerly breeding grounds. Journal of Avian Biology 36: 117-126.

Spina, F., Massi, A., Montemaggiori, A. \& Baccetti, N. 1993. Spring migration across central Mediterranean: general results from the "Proggeto Piccole Isole". Vogelwarte 37: $1-94$.

Stervander M, Lindström Å, Jonzén N. \& Andersson A. 2005. Timing of spring migration in birds: long-term trends, North Atlantic Oscillation and the significance of different migration routes. Journal of Avian Biology 36: 210-221.

Svensson, L. 1992. Identification guide to European passerines. 4th ed. Author's edition, Stockholm.

Thorup, K., Tøttrup, A. P. \& Rahbek, C. 2007. Patterns of phenological changes in migratory birds. Oecologia 151: 697-703.

Tottrup, A. P., Thorup, K., Rainio, K., Yosef, R., Lehikoinen, E. \& Rahbek, C. 2008. Avian migrants adjust migration in response to environmental conditions en route. Biol. Lett. 4(6): 685-688

Valkama, J., Saurola, P., Lehikoinen, A., Lehikoinen, E., Piha, M., Sola, P. \& Velmala, W. 2014. The Finnish Bird Ringing Atlas. Vol. II. Finnish Museum of Natural History LUOMUS \& Ministry of Environment, Helsinki.

Waldenström, J., Ottosson, U. \& Haas, F. 2004. Morphometrical data from 30 bird species on spring migration in northern Tunisia. Ornis Svecica 14: 129-133.

Widmer, M. \& Biebach, H. 2001. Changes in body condition from spring migration to reproduction in the garden warbler Sylvia borin: a comparison of a lowland and a mountain population. Ardea 89: 57-68.

Yohannes, E., Biebach, H., Nikolaus, G. \& Pearson, D. J. 2009a. Migration speeds among eleven species of long-distance migrating passerines across Europe, the desert and eastern Africa. Journal of Avian Biology 40: 126-134.

Yohannes, E., Biebach, H., Nikolaus, G. \& Pearson, D. J. 2009b. Passerine migration strategies and body mass variation along geographic sectors across East Africa, the Middle East and the Arabian Peninsula. Journal of Ornithology 150: 369-381.

\section{Sammanfattning}

Under vårflyttningen anses långdistansflyttande fåglar ofta följa en tidsminimerande strategi för att därigenom möjliggöra en tidig ankomst till häckningsplatserna. I flera fall har det visats att vårflyttningen sker under en kortare tidsperiod än höstflyttningen. Långdistansflyttande arter som häckar i Europa och övervintrar i Afrika söder om Sahara måste passera geografiska områden som varierar högst avsevärt och det innebär att fåglarna måste hantera vitt skilda förhållanden som kan påverka flyttningshasighet och energireserver. Fördelen 
med en tidig ankomst till häckningsplatsen måste balanseras mot nackdelar och det kan vara en fördel att anlända med en extra energireserv som en förberedelse för häckningen och som en försäkran mot dåligt väder och begränsad födotillgång.

I denna studie har det tidsmässiga uppträdandet och energireserver hos fyra långdistansflyttande arter, härmsångare, grönsångare, grå flugsnappare och halsbandsflugsnappare, jämförts mellan en fågelstation i Grekland, Antikythira, och en i Sverige, Hoburgen (Sundre fågelstation). De fyra arterna häckar i en stor del av norra Europa, med undantag för halsbandsflugsnapparen som häckar på Gotland och Öland. Gemensamt för arterna är att de har en nordlig flyttningsriktning genom Europa på våren och det är därmed rimligt att anta att en del av de som passerar Antikythira är på väg till häckningsplatser i norra Europa och passerar Hoburgen. Skillnaden i uppträdande mellan de två platserna har använts för att beräkna en genomsnittlig flyttningshastighet.

Vid båda fågelstationerna sker standardiserad daglig fångst av flyttfåglar, vid Antikythira från slutet av mars till slutet av maj och vid Hoburgen från 25 april till 8 juni. I samband med att fåglarna ringmärkts har uppgifter om vinglängd, vikt och fettklass insamlats.

Antalet fåglar av de fyra arterna som fångades under de åtta vårarna uppgår till 4157 vid Antikythira och till 1062 vid Hoburgen (Tabell 1). Halsbandsflugsnapparen var den art som anlände tidigast till Europa och härmsångaren anlände senast. Mediandatum för de olika arternas passage vid Antikythira varierade mellan 19 april och 8 maj och vid Hoburgen mellan 8 och 27 maj. Flyttningspassagen var genomgående mer hoptryckt tidsmässigt vid Hoburgen än vid Antikythira (Figur 1b), vilket kan bero på att fåglar som passerar Hoburgen är på väg till häckningsområden som är geografiskt mer avgränsade än vad som gäller för fåglar som passerar Antikythira. Den beräknade flyttningshastigheten varierade mellan 129 och $137 \mathrm{~km} /$ dag och var inte signifikant skild mellan de olika arterna (Tabell 2). Hos härmsångare, grönsångare och grå flugsnappare fanns ett signifikant samband mellan mediandatum vid Antikythira och flyttningshastighet, vilket innebär att år när fåglarna anländer sent sker flyttningen snabbare genom Europa. Härmsångare och grå flugsnappare hade något längre vinglängd på Antikythira medan grönsångare och halsbandsflugsnappare inte uppvisade någon skillnad mellan platserna. Orsaken till detta skulle kunna vara att en större andel av grå flugsnapparna och härmsångarna som passerar
Antikythira är på väg till andra häckningsområden än fåglarna som passerar Hoburgen jämfört med vad som gäller för grönsångarna och halsbandsflugsnapparna. Den genomsnittliga vikten hos de studerade arterna var signifikant lägre för alla arter på Antikythira jämfört med Hoburgen (Tabell 3). Detsamma gällde fettklassificeringen, även om något olika skalor användes.

Resultaten visar att det tar i genomsnitt 3-4 veckor för arterna att passera igenom Europa och de första individerna började anlända till Hoburgen innan de sista passerat Antikythira. När det gäller härmsångare och grönsångare anländer de första till Gotland bara några dagar efter mediandatum på Antikythira. Det tidsmässiga uppträdandet i Grekland överensstämmer ganska väl med vad som publicerats för andra delar av Medelhavet. Ett undantag gäller härmsångare som tycks anlända något senare till västra Medelhavet. Passagen av Gotland ligger helt i linje med vad som tidigare publicerats för Ottenby på Öland. Fåglarna som anländer till Antikythira har precis passerat Sahara och detta avspeglas väldigt tydligt $\mathrm{i}$ låga vikter och små fettreserver. Att fåglar anländer till Medelhavsområdet helt utan energireserver har noterats vid flera tillfällen. De vikter som noterades hos fåglar på Antikythira ligger inom ramen för vad som noterats tidigare i andra delar av Medelhavet. Ett undantag utgör härmsångarna som $\mathrm{i}$ genomsnitt vägde mer när de anlände till Antikythira än vad man funnit hos fåglar som anländer till centrala Medelhavet, vilket antyder att de kan ha fettupplagrat i Nordafrika. Efter att fåglarna passerat drygt $2000 \mathrm{~km}$ över kontinentala Europa och Östersjön uppvisar fåglarna klart högre vikter och mer synligt fett. Att bära på en extra reserv kan vara en förberedelse för ankomsten till häckningsplatserna.

De flyttningshastigheter som visats i denna studie ligger i linje med vad som tidigare påvisats och är högre än vad som erhållits från arterna under höstflyttningen. Man skulle kunna förvänta sig att arter som anländer senare har en högre genomsnittlig hastighet, något som denna studie inte kunde visa. Att hastigheten var högre under år när ankomsten var relativt sen till Antikythira är intressant och kan antyda att fåglarna kompenserar en sen ankomst med en högre hastighet så att de trots allt anländer i tid till häckningsplatsen. $\AA$ andra sidan kan förhållandena vara sämre tidigt under våren och därmed begränsa flyttningshastigheten under år när fåglarna anländer tidigt. Det faktum att ingen större skillnad kunde hittas mellan arterna antyder att så inte är fallet. 